\title{
National encounters between Indigenous and settler peoples: some Canadian lessons
}

Ravi de Costa

\section{Introduction}

The most complex projects facing formerly colonial nation-states may be their attempts to create new and lasting arrangements between descendants of Indigenous and settler peoples which meet all their aspirations and needs. Many advocates focus on a constitutional or at least a legislative process by which to reach such arrangements, most commonly called treaties.

In this paper, I examine what some think is the most systematic and comprehensive post-colonial process ever devised: the British Columbia treaty process. I describe the process variously, using the figure of national encounters, in order to draw attention to the most misunderstood aspect of treaty-making. Treaties, I argue, are not simply the single encounter of coherent Indigenous and settler communities: the solemn and dignified exchange of recognition between the elders of two very different tribes. In fact, and against most of the representation of treaty-making, they are at least as much processes of these communities encountering themselves in their diversity. We see this diversity in the array of needs and the panoply of institutions that must be satisfied for treaties to work; the past must be served no less than the present and future. Each part of the putative community encounters others as well as encountering the parts of the 'other side' in a process of dizzying complexity.

This suggests a much harder task than many have envisaged. The question of community stability and coherence within liberal-democratic societies like Canada and Australia is increasingly under discussion as social, economic and cultural change now appears a permanent feature of life; Indigenous communities face many similar challenges in addition to the often very basic imperatives to survive as communities in the face of degrading economic and social circumstances as well as pressures to assimilate. Treaties cannot be seen as some magical device for restoring balance throughout these diverse social formations; they are better seen as a framework to enable different parts of a nation to encounter each other in dialogue and negotiation.

\section{Old encounters: the long path to a treaty process in British Columbia}

There is a long and complex history of treaty-making in Canada. With few exceptions, this history does not encompass British Columbia. ${ }^{1}$ An explanation for this can be found in the

\footnotetext{
${ }^{1}$ The main exceptions are the Douglas treaties reached on Vancouver Island in the 1860 s. Other agreements are the source of some historical interest, notably the Barricade treaties reached between authorities and the Carrier peoples around the Prince George area in the early 1900 . The 1908 agreement, Treaty 8, straddled the Alberta-British Columbia border. It was the subject of an adhesion by the McLeod Lake Band in
}

2000 , who have recently entered the treaty process in order to achieve self-government, something not part of the old 'numbered' treaties. The only 'modern' treaty is the Nisga'a Final Agreement (NFA) also concluded in 2000 but reached through a separate process known as the comprehensive claims policy. 
differing interpretations made by colonial authorities of the 1763 Royal Proclamation, which reserved all lands west of the Rocky Mountains as the hunting grounds for Indians. Without recounting that entire history, it is important to note that the colony (and Province after 1871) of British Columbia observed neither the intention of the Proclamation nor the facts of Native possession. In effect, British Columbia was considered terra nullius or empty land.

This assumption was frequently challenged by Native peoples. ${ }^{2}$ However, early political representations were largely ignored and from 1927-51, land claims activity by Natives was prohibited by amendments to the Indian Act. ${ }^{3}$ Soon after the prohibition was lifted, the exceptionalism of British Columbia, in not having negotiated the status of Native peoples through treaties, began to come under increased pressure from three related sources: direct action by Native peoples; more favourable jurisprudence; and shifts in federal policy.

From 1951 there was a rapid evolution of organisational structures and political strategy for Native land claims. A range of bodies emerged to make their claims, including the Native Brotherhood of British Columbia, the Union of British Columbia Indian Chiefs, the British Columbia Association of Non-Status Indians, the Alliance of British Columbia Indian Bands and the United Native Nations. ${ }^{4}$ Though the styles and goals varied, land was a crucial issue for all. Government intransigence in the face of these developments was soon reflected in a rise in direct action across the Province.

Tennant suggested that 1973 saw the start of 'the contemporary era of BC Indian political protest', the timing influenced by events at Wounded Knee in South Dakota. ${ }^{5}$ Activities soon mushroomed: blockades of logging roads and government offices; protest marches; obstruction of railway development; and, particularly the assertion of traditional resource rights. ${ }^{6}$ George Manuel, a highly influential British Columbia Native leader called for 'sophisticated civil disobedience', referring to an 'army' of activists who would take up arms in the struggle if necessary. ${ }^{7}$

By the early 1980s, direct action targeted resources industries systematically. Such was their effect through that decade that in 1989, David Mitchell, a member of the provincial Cabinet and Vice-President of the lumber company Westar, described Provincial authority as having in some areas broken down completely: 'it is no longer certain who controls the forests in northwest British Columbia'. ${ }^{8}$ This was a crisis in an economy so heavily dependent on the resources sector for jobs and export earnings. Forestry products are especially important: Canada is the world's largest exporter of forest products, a third of which come from British Columbia. ${ }^{9}$ This equates to over CAN\$15B in export revenue, half of the total value of exports from the Province, and nearly $5 \%$ of total exports from the whole of Canada. Though employment levels are declining, over 100,000 people are still directly employed by the sector in a workforce of $1.9 \mathrm{~m} .{ }^{10}$

Secondly, jurisprudence around aboriginal rights and title started to change rapidly. Initially the province responded to land claims by refusing any acknowledgment and mobilising denials

\footnotetext{
2 For clarity, I use the term Native(s) to refer to all indigenous peoples in the Province; First Nation(s) is restricted to those peoples involved in the treaty process.

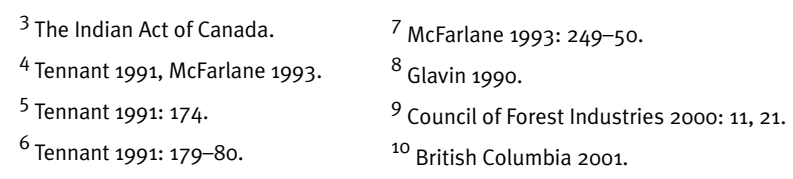


such as the 'tense'11 argument and the 'implicit extinguishment' ${ }^{12}$ position. In 1973 the title claim of the Nisga'a, litigated since the 1960s, reached the Supreme Court of Canada in Calder v Attorney-General of British Columbia. ${ }^{13}$

The Calder decision found that the Nisga'a had held aboriginal title before settlers came, though the judges split over the question of the continuing existence of their title. In their obiter dicta, the judges decided that Aboriginal title did not depend upon the 1763 Royal Proclamation, but on proof of occupation since 'time immemorial'; extinguishment by the Crown must be 'clear and plain'. ${ }^{14} \mathrm{~A}$ busy period of litigation ensued which extended the scope of potential aboriginal title while increasingly developing its content. The de facto attitude of the Province that its territory was terra nullius was becoming increasingly untenable.

The British Columbia Supreme Court deepened the doubts over government authority and tenure, granting injunctions against resource activities in various corners of the territory: on Vancouver Island, in the remote north-east of the Province, in the southern Okanagan Valley and on the North Coast, injunctions allowed for the possibility of continuing title. At McLeod Lake, a protest that involved unsanctioned logging gave rise to a ruling that allowed the band to sell their 'illegal' timber. ${ }^{15}$

A direct consequence of the reforming jurisprudence - and the third source of pressure on provincial exceptionalism - was federal policy reform. After Calder, Prime Minister Trudeau directed the Indian Claims Commission (which had hitherto dealt only with grievances under the older treaties) to start hearing non-treaty claims directly and the comprehensive claims policy was begun. ${ }^{16}$ Foster calls this the 'third period' of treaty-making in Canada. ${ }^{17}$ There have been a range of settlements reached under that process, though it must be pointed that none of these deal with the populous parts of Canada.

Federal policy had been to negotiate only one claim at a time, resulting in a situation where although many British Columbia Native groups had joined up through the 1980s, 'the line had not moved'. ${ }^{18}$ As a bilateral set of negotiations between Native communities and Canada, comprehensive claims presented a vexed question over land: more than $90 \%$ of Crown land in British Columbia is vested in the Province, and the courts had determined that federal appropriations of Crown land must be done with provincial agreement.

However, by the 1980s, these pressures, as well as the rise of the conservation movement and a declining market for forestry commodities were making the Province's position less sound. Upon the election of the Vander Zalm government in 1986, the Social Credit party took a more pragmatic stance and by 1989 figures like Jack Weisgerber and Eric Denhoff were revealing fresh thinking within the conservative party. In Weisgerber's speech endorsing the treaty process in 1993, he acknowledged this prior 'strategy of denial' at length: 'We maintained that there was no issue there to discuss. If there was, it was in our minds clearly a federal responsibility and shouldn't involve the province, and we tended to avoid it. ${ }^{19}$

\footnotetext{
${ }^{11}$ The view that confederation had annulled aboriginal title.

${ }^{12}$ The view that any provincial assertion through legislation automatically extinguished title. See Tennant 1991: 216-18.

${ }^{13}$ Calder v Attorney-General of British Columbia [1973] SCR 313.
}

${ }^{14}$ Calder v Attorney-General of British Columbia [1973] SCR 313.

${ }^{15}$ Tennant 1991: 225.

${ }^{16}$ Tennant 1991: 172.

${ }^{17}$ The first being the pre-

Confederation treaties made prior to 1867 ; the second the 'numbered treaties' from Treaty 1 in southern

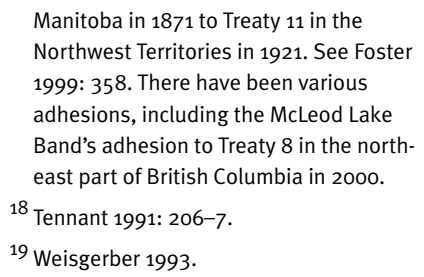




\section{Managing the encounter: the process of treaty-making}

The British Columbia Treaty Commission Agreement (the Agreement), was reached in 1992 between three 'principals': the governments of Canada and British Columbia, and the First Nations Summit (FNS), a body bringing together the leadership of communities representing some $70 \%$ of British Columbia's Native population. It in turn endorsed an earlier report commissioned by the provincial government, the British Columbia Claims Task Force Report (the Report), which is the foundational and substantive text of modern treaty-making in British Columbia. ${ }^{20}$ It made 19 recommendations, and most unusually for a report of its type, all were quickly adopted by both the two governments and the FNS.

Under the terms of the Agreement, the British Columbia Treaty Commission (the Commission) was legislated for in 1993. There would be five treaty commissioners: two appointed by the FNS, one by British Columbia and one by Canada; the Chief Commissioner appointed by mutual consent of the principals. The Report had suggested that the parties negotiate any issues of interest to them and described explicitly how tripartite negotiations would proceed between the province, Canada, and individual First Nations: each set of negotiations in the process - each treaty 'table' - would go through 6 stages. ${ }^{21}$

First Nations initiate the process, each Native group indicating their voluntary participation, setting out who they are and the extent of their traditional territory (Stage 1). This is known as a Statement of Intent (SOI). Then the First Nation and the two governments have to demonstrate their 'mandate', their capacity to negotiate and ratify agreements, ${ }^{22}$ and the measures for public consultation they intend to put in place (Stage 2). Once the Commission was satisfied each treaty table was declared ready.

Initial discussions could then begin: what would be the table structure - would there be sidetables to deal with wildlife or taxation issues, for example? The main aim is to get an agenda for future negotiations, a 'Framework Agreement' (Stage 3). This needed to be ratified according to the procedures set out at Stage 2. Substantive negotiations could then begin, working towards drafts of chapters that would become the final text of the treaty. A collection of draft chapters is an 'Agreement-In-Principle' (AIP), which again, requires ratification (Stage 4).

Finally, negotiations would arrive at the final text of Agreement. Here a process of constitutional and legal review is undertaken in addition to further discussions at the table (Stage 5). Effectively the conclusion of negotiations, this document naturally requires ratification by all three parties, using the approach they had committed to at the outset. After this, only implementation of the Final Agreement remains (Stage 6). Once complete, the Final Agreement has the status of an Aboriginal Treaty under section 35 of the Constitution. While the structure of the process invites few criticisms, in practice its operations are the source of considerable frustration. It is worth considering briefly the issues of interest-based negotiations and debt.

\section{Funding}

One of the key decisions taken by the principals had been to make First Nations' access to funds (for lawyers, anthropologists, oral history studies etc) largely dependent on loans. Negotiation

\footnotetext{
${ }^{20}$ British Columbia 1991.

${ }^{21}$ BCTC 1999C.

${ }^{22}$ First Nations decided that ratifications would be by community referendum. British Columbia and Canada decided that agreements would be ratified by passage through the Legislature and Parliament respectively.
} 
Support Funding, as it is known, is $80 \%$ a loan from Canada, and $20 \%$ a grant which Canada and British Columbia split 60/40. Throughout the process this system has been managed by the Commission: $\$ 255 \mathrm{~m}$ has been disbursed, $\$ 204 \mathrm{~m}$ as loans. ${ }^{23}$ Loans are due seven years after a table reaches an AIP, and 12 years after the first loan if talks break down. Yet many First Nations object to the very principle of loans. Why, they ask, should Native people go into debt so that settler governments can rationalise Native rights into the dominant political system? It is a reasonable criticism, made compelling by the fiscal weakness of most Native communities in the province.

\section{Interest-based negotiations}

A second issue concerns the way in which negotiations are conducted. The clear intention of

the principals at the outset of the treaty process was that negotiations would adopt an 'interestbased' form of negotiation. A participant in the process explained the rationale:

Essentially there's two models of negotiation, there's interest-based, and there's the typical competitive labour-union kind of model. And we came into the process saying 'no, we don't want to compete, we don't want to hide our cards and only put the ones out on the table that we think we should'. ${ }^{24}$

So, an 'interest' for Natives might be something like ensuring that zoning or resources decisions were highly sensitive to concerns for traditional burial grounds. This contrasts with the 'position' that Native groups must control the zoning or resource allocation processes themselves. One of the intentions of this alternative model of negotiation was to help create good will and trust among the parties. ${ }^{25}$ It often seems not to have arisen. Although relations between individuals on tables are often good, it has been the view of First Nations that the two government's negotiators do not come and negotiate, but calculate their bottom-line away from treaty tables. Such criticism takes on a new force after the 1999 British Columbia Supreme Court ruling in Luuxhon, ${ }^{26}$ which confirmed the requirement that negotiations, once commenced by government, must be continued in good faith. ${ }^{27}$ Accusations of negotiating in 'bad faith' now encourage a legalistic interpretation, and though the definition of 'good faith' is still unclear, this may be the foundation on which First Nations build their criticisms of the British Columbia treaty process in years to come. ${ }^{28}$

\section{Encountering the issues at treaty tables}

These problems in the structure of the negotiating process, though not insurmountable, have drained much of the initial euphoria; it was a sense of optimism and trust that had been thought crucial to the timely conclusion of treaties. However, minimal progress on the substantive questions has raised doubts amongst many observers about whether comprehensive agreements may ever be reached: momentum continues to erode, while alternatives are being explored.

As noted above, theoretically nothing is ruled out on treaty tables, though this is far from the reality. I will demonstrate this, and explore some of the associated tensions, by briefly considering several of the issues the parties have been failing to resolve over the last ten years: land 'quantum' and interim measures; compensation; and 'certainty'.

\footnotetext{
${ }^{23}$ BCTC 2003b: $40 . \quad \quad 26$ Luuxhon et al v HMTQ Canda et and Nisga'a [2000]. BCSC 1332.

24 Didluck 2000.

${ }^{25}$ Govier $2000 . \quad{ }^{28}$ The Snuneymuxw, for example, appeared awake to the strategic value of the 'bad faith' line in their negotiations during 2000. See Wagg 2000
} 


\section{Quantum and interim measures}

Quantum refers to the package comprising both what the governments envisage as 'treaty settlement lands, ${ }^{29}$ as well as cash to fund Native administration and development. Reaching agreement in this area has been a frustrating experience, not least in urban areas where little Crown land is available and very large cash sums are being proposed by First Nations. In some cases, agreements on quantum have been reached at tables which have then not gained community acceptance. The reasons for this may be found deeper, in Native attitudes to their history of subjugation and to particular visions of their future, of entitlements based in ongoing identities. However, there appears to be some evidence that after 10 years of the process, First Nations may reach acceptable packages of land and cash settlements. I discuss recent developments on four treaty tables near the conclusion of this paper.

For the bulk of First Nations who have not reached this part of an agreement there remains great dissatisfaction with the implementation of the interim measures policy. The Report had recognised that treaties would take time, explicitly recommending a process for the protection and sharing of lands and resources before each treaty was concluded. A range of interim measure options was contemplated: 1) notification of potential impacts on issues that may be discussed at treaty tables, particularly unilateral action on lands and resources; 2) consultation over that action; 3) consent for such initiatives; 4) joint management processes requiring consensus; and 5) restrictions or moratoria on land and resource use. ${ }^{30}$ The Supreme Court ruling in Delgamuuk'w (dealt with below) clearly confirms the wisdom of this policy, and as McNeil has argued, characterised resource activities as requiring Native involvement. ${ }^{31}$ Yet First Nations have been extremely dissatisfied with the interim measure policy. Again, the province has been reluctant to contemplate interim arrangements until tables reach stage 4 . Chief Treaty Commissioner Miles Richardson pointed out the problem with such policy:

First Nations are largely saying, and I think quite legitimately that, 'it's just not on that we continue sitting negotiating at treaty tables accumulating huge amounts of debt when the very assets, the very resources that we're talking about are rolling by our offices on logging trucks' $^{32}$

In its 2001 review of the process, Looking Back, Looking Forward, the Commission pointed out that, of 60 recently agreed measures, only one was a land protection agreement. ${ }^{33}$ The 2002 First Nations Economic Measures Fund of \$30m keeps entirely within these parameters. More recently there has been some discussions about 'incrementalism', which would see the constitutional protection of some aspects of an agreement before others, as a way of testing out agreements and building good faith. This could mean 'fast-tracking' some parts of an agreement through stages 4-6, leaving areas of disagreement for future negotiations. As yet, no concrete proposals for this have emerged from the principals.

\section{Compensation}

The Task Force Report clearly advocated compensation at recommendation 2, allowing for discussions without 'unilateral restriction'. Moreover, it noted that negotiations may 'include consideration of a financial component to recognise past use of land and resources and First

\footnotetext{
${ }^{29}$ That is, land that after treaties will be under the $\quad{ }^{31}$ McNeil 1998: 13 . exclusive ownership and jurisdiction of FNs. $\quad 32$ Richardson 2000.

30 British Columbia 1991: Recommendation $16 . \quad 33$ BCTC 2001C: 11.
} 
extinguishment, even though the denial of potential future rights while so many legal doubts remain seems contrary to this.

Many Natives discuss an altogether different idea of certainty. During the Senate hearings as part of the federal government's ratification of the NFA in early 2000, a Gitxsan elder spoke of their desire for 'a set of living agreements', of partnerships between peoples that were flexible and respectful. ${ }^{47}$ No concept in Native-settler relations is more fetishized than certainty - but the British Columbia treaty process lays bare the question: is 'certainty' the recognition of Native rights, or an indemnity against their future assertion? It is clearly the case that some in British Columbia feel that the modification of their rights envisaged by the governments is tantamount to a negation of their inherent status as Native peoples. Certainty appears to be an aspect of the treaty-process that reflects an out-dated conception of what treaties are or can be. The concept implies the end of the encounter rather than its beginning.

\section{Legal encounters}

In December of 1997, the Supreme Court of Canada gave its judgment in the case known as Delgamuuk'w. ${ }^{48}$ While there was no determination on the specific question of the aboriginal title of the Gitxsan-Wetsuweten (a First Nation in northern British Columbia), the ruling had major ramifications for the treaty process which continue to be grappled with. The court encouraged 'negotiated settlements with good faith and give and take on all sides'. ${ }^{49}$ The judgment then established a new context for such negotiations, by developing a clearer definition of aboriginal title: neither an inalienable form of fee simple nor mere usufructuary (usage) rights, it is 'somewhere in between these positions'. Aboriginal title is a right in land itself, and can encompass a range of practices 'not all of which need be ... integral to the distinctive cultures of aboriginal societies'. The opening provided here is the source of ongoing dispute, though such practices cannot include those which would threaten the aboriginal way of life itself. ${ }^{50}$ This elaboration of aboriginal title gives further content to s.35. However, it is certain that title is not immune from infringement by the Federal government. In fact the opposite is true:

[T] he development of agriculture, forestry, mining, and hydroelectric power, the general economic development of the interior of British Columbia, protection of the environment or endangered species, the building of infrastructure and the settlement of foreign populations to support those aims, are the kinds of objectives that are consistent with this purpose and, in principle, can justify the infringement of aboriginal title. ${ }^{51}$

Persky suggested that the wide scope of the phrase 'general economic development' may be minimised by the requirement to consult and an obligation to pay compensation where infringement occurs. ${ }^{52}$ The exhortation of the court for parties to negotiate rather than litigate is notable, although it has many precedents, such as in the widely-cited Martin case in the British Columbia Court of Appeal, which provided injunctive relief against logging activity to a First Nation on Vancouver Island in 1985. That judge remarked that the people of British

\footnotetext{
47 Derrick 2000.

48 Delgamuuk'w v British Columbia [1977]. 3SCR 1010. For a comprehensive analysis of the judgment see the range of scholarly articles available at http://www.delgamuukw.org
}

\footnotetext{
49 Delgamuuk'w v British Columbia [1977]. 3SCR 1010: at para 186.

50 Delgamuuk'w v British Columbia [1977] 3SCR 1010: at paras 110-11

${ }^{51}$ Delgamuuk'w v British Columbia [1977] 3SCR 1010: at para 165.

52 Persky 1998: 20.
} 
Columbia were entitled to think that their leadership would negotiate reasonable outcomes on their behalf without the accumulating costs and enmity of litigation.

Several points may be raised, however: exhortations to negotiate, like those for peace, can often elide questions of power, a fact not lost on First Nations, governments or observers of the treaty process. Moreover, the judgment downplayed a number of issues that have proven consistently beyond the abilities of negotiating teams. These include the range of activities and the character of aboriginal jurisdiction or self-government over title lands; the specifics of good faith consultation; and an appropriate level of compensation for extinguished title.

Indeed, a new wave of litigation is underway. ${ }^{53}$ In recent jurisprudence in the Supreme Court of Canada, First Nations gained a recognition they had long sought on treaty tables without success: the right to be consulted over resource allocation decisions on lands the legal status of which remains in dispute. In the Haida judgment, the court pointed to an infringement of that duty and extended it to the corporation involved, lumber multinational Weyerhauser. ${ }^{54}$ Such recognition has been at the centre of Native demands since they realised that Europeans intended to settle in their traditional territories. Indeed, part of the energy created by the treaty process at its inception, was its apparent openness to Native interests over resource allocation decisions in advance of final determinations of title. The interim measures process, as I have pointed out, leaves much to be desired. So, in the absence of widespread confidence in negotiations, litigation is seen by First Nations as one way of extending their recognition within Canadian institutions. Their resources, numbers and politically marginal status, will, I suggest, ensure that this remains the case.

Yet, treaty-making must deal with the fact that Indigenous people in Canada are rightsbearing individuals like all Canadians; jurisprudential interest in treaties is not likely to be confined to constitutional discussions about relations between governments. Comprehensive negotiations are also subject to developments in other democratic processes. A recent judgment in the British Columbia Provincial Court, $R v$ Kapp et al [2003], ruled as unconstitutional the 12-year old Pilot Sales Agreement that set up Native-only fisheries. Justice William Kitchen felt that, 'the most troubling aspect of this discrimination is that it is government sponsored. The government should be setting an example for the rest of society, but unfortunately, this has not been our history. ${ }^{.55}$ Begun in 1992 as a way to both acknowledge Native rights and provide jobs and revenue for Native communities, this program was certainly part of the calculations of First Nations working on treaties. ${ }^{56}$

\section{The status of the encounter}

Fifty-five First Nations are involved in the BC treaty process. Several First Nations sit at joint tables, meaning there are 44 tables. Only two Indigenous groups have joined the process since the Delgamunk'w judgment of late 1997. Others have deprioritised negotiations, some have formally withdrawn. The bulk of First Nations are entrenched in the first substantive phase of negotiations, working towards an AIP. However, five tables have now reached Stage 5, though one, the Sechelt, have been in litigation against the Province since 2000. Before considering what these agreements have achieved, it is necessary to consider the context of treaty or agreement-making within a democratic setting like contemporary British Columbia.

\footnotetext{
53 BCTC 2004: 2.

54 Haida Nation v British Columbia (Minister of Forests) [2004] 3SCR 511.

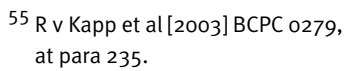


During the passage of the enabling provincial legislation in 1992, one event pointed to future complexity: though there was unanimity on the need for comprehensive negotiations, the then NDP government arranged for a reception to celebrate the passage of the bill and the dawn of a new relationship between the peoples. It was planned in advance of the bill's presentation to the Legislature and clearly it was thought that Legislative approval was a mere formality; the real agreement had really taken place between government and the First Nations Summit. The Leader of the Opposition, Gordon Wilson, found this 'contemptuous' of the role of the Legislature, though this did not stop him and his party from supporting the bill. ${ }^{57}$

As negotiations began to deal with substance on issues like fiscal relations, land quantum and self-government, the merely formal role of the Legislature became untenable and bipartisanship began quickly to dissolve. By the mid-1990s there was a chorus of disapproval about the lack of transparency and accountability in treaty-making. It began within resource industry groups hostile to any transfer of control over resources to Native peoples, but quickly found a political ally in the provincial Liberal party. ${ }^{58}$ The ratification of the Nisga'a AIP in 1996 gave this campaign a great deal of momentum and set the ground for the referendum policy. When the Nisga'a Final Agreement came before the Legislature in 1999, the government rejected the myriad amendments proposed by the Liberal opposition. After the longest provincial debate ever on a single bill, the government used its numbers to close debate and force a vote; the Opposition voted against ratification but were defeated. Party unanimity on treaties was gone and a nasty period ensued where treaty-making was smeared as undemocratic. ${ }^{59}$

Negotiations continued through the late 1990s but produced negligible results, with a number of First Nations abandoning or downgrading their negotiations. In May $2001 \mathrm{a}$ provincial election in British Columbia radically changed the political landscape: the NDP was tossed out of office, with the Liberals taking 77 of 79 seats in the Legislature. The new government began implementing their only policy on treaties: a referendum to determine what the Provincial government's 'mandate' at treaty tables would be. Consequently, eight referendum questions were put to provincial voters in $2002 .{ }^{60}$ These set out principles on issues such as self-government, recreational access to resources, and the protection of private (non-Indigenous) property, which if approved, would become binding under provincial law on treaty negotiators. Much of this was too vague to be helpful: recreational access to which resources, under what circumstances? Other questions were transparently malicious in their presentation of issues which had not arisen at tables, such as the idea that private fee simple (freehold) land might be expropriated.

The entire referendum demonstrated how close the accumulated history of conflict was beneath the surface of an established process. Boycotts by Native peoples and their supporters, including public ballot burning, raised the temperature around Native issues, but also ensured that majority support for the measures would be overwhelming. ${ }^{61}$ None of the eight questions was approved by less than $84 \%$ of voters, with many receiving over $90 \%$ approval.

The full effect of this referendum is not yet clear, though it may already be producing new approaches to the issue of self-government. The referendum had asked voters whether they thought that Native self-government should be 'municipal'; that is, delegated from the

\footnotetext{
57 Wilson 1993. $\quad 59$ McInnes 1999, Willcocks 1999. ${ }^{58}$ de Costa 2002: 311-22. $\quad{ }^{60}$ See BCTC 2002a. $\quad$ Coalition 2002.

${ }^{61}$ Inwood 2001, Aboriginal Rights
} 
Province, as is the case for local government. This was resoundingly approved, though it flatly contradicts the federal government's 1995 policy of an inherent right to self-government. ${ }^{62} \mathrm{In}$ the year since the referendum, several AIPs have come out of tables around the Province, but no uniform approach to governance is visible: several drafts see the parties consent to a Native government but agree that it will be a separate document, not part of the main treaty and not protected by the Constitution. Moreover, the government will exist only for a fixed (unstated) term and will be subject to review by the parties at that time. Others, such as that reached by the Tsawwassen First Nation include a categorical statement that its self-government will be a section 35 right. The Lheidli T'enneh First Nation's AIP provides for some aspects to be protected with others reviewable. It is far from clear how this will square with the result of the referendum and what the effects on the government's legitimacy will be. Elsewhere in provincial politics, a populist and majoritarian vision of democracy is gathering steam, with a Province-wide Citizen's Assembly on electoral reform well underway. ${ }^{63}$

Indigenous leaders at treaty tables must also satisfy their constituents. Throughout the history of the process, a significant number of substantive agreements made at treaty tables (that is, stage 4 agreements on an AIP) have been rejected by Native communities: this suggests that there may be discontinuities between the leadership negotiating the agreement and the community itself. For example, on 21 June 2003 Snuneymuxw First Nation were scheduled to hold a ratification vote for the AIP initialled at their table in March of that year. Jeff Thomas of the Snuneymuxw Treaty Office described why this did not happen: 'We had quite a number of our membership come forward that were not comfortable with the AIP. They did not understand enough to be comfortable in voting. ${ }^{34}$ The AIP was finally ratified in 2004.

Part of the difficulties faced by Native people in terms of ratification is the realisation that such agreements will increase the power of their own leaderships. During the ratification of the Nisga'a Final Agreement (conducted outside the BC process but in a substantially similar manner), the final vote to ratify the agreement included a ballot on a future Nisga' a constitution that had at the time not been seen by the Nisga'a community. ${ }^{65}$ The challenges to be faced by indigenous people in developing the capacity to realise the promise of these agreements and to trust in the new political and governing structures they create, are hardly insignificant.

Notwithstanding this, several AIPs have been reached with four active tables now in Stage 5 of the process. The Sliammon, Tsawwassen, Lheidli T'enneh and Maa-nulth communities have reached substantive agreements on a range of issues, though the headline in each case is a mutual position about the 'quantum' each First Nation will receive. Yet crucial issues remain unaddressed, including governance, compensation and certainty. ${ }^{66}$

The Treaty Commission itself may be seen as a barometer of real progress however. The limits of its authority as delegated by Canada, the province and by First Nations remain a visible marker of the difficulties inherent in making treaties. A recent independent review found it to be less than effective in key areas of helping parties reach timely agreements and in its task of keeping the general public informed and supportive. ${ }^{67}$ The burden of managing a process in which so many parts of communities must encounter and negotiate with each other appears to be showing. Its Annual Report for 2003 was plaintively titled 'Where are we?'. ${ }^{68}$

\footnotetext{
62 Canada 1995.

${ }^{63}$ See http://www.citizenassembly.bc.ca/citizenassembly.html

${ }^{64}$ Thomas 2003.

${ }^{65}$ Rinehart 1998a, 1998b.

${ }^{66}$ BCTC 2003b: 9-13.

${ }^{67}$ Deloitte \& Touche 2003: 3-10.

${ }^{68}$ BCTC 2003b.
} 


\section{Conclusion}

Robert Williams's history of early treaties in North America finds that, for American Indians, early colonial treaties embodied trust by making personal connections and sharing stories. These highly symbolic 'acts of commitment', such as exchanges of gifts or smoking a common pipe, enabled shared processes of justice to begin. ${ }^{69}$ In the words of Annette Beier, this is 'made settled by the fact that the first or early performers' example is followed, their confidence confirmed, general expectation of further conformity strengthened and so a general custom launched'..$^{70}$

Modern treaties look nothing like this. In British Columbia, discussion at treaty tables provides neither Native nor settler communities with models of exemplary behaviour, other than perhaps the commonsense principle that it is good for people to talk to each other. In fact, treaty negotiations are highly technical expressions of future systems of rule; the codification of exemplary behaviour, rather than its performance. It could be no other way. Compared to the early colonial examples, both 'sides' are far less homogenous than they were; connections between the two are now innumerable; and structures of legitimacy and authority radically different. The hope that senior figures might enact a performance (or text) that was wholly representative, widely supported and yet aspirational, appears lost amid the regulation and alienation of modern life.

These national encounters must take account of a bewildering number of constituencies, institutions and demands, including the jurisprudential context; the imperative for transparent and democratic processes; the need for swift and cheap results; and the permanent disaffection of some on both sides. Australians, like those in British Columbia and elsewhere who are working towards some resolution of the unfinished business of colonialism, must accept the complexity of the national encounter that is at stake. In do doing, they must be prepared to work on many fronts and to perhaps forgo perfection.

\footnotetext{
${ }^{69}$ Williams 1997: $125 . \quad{ }^{70}$ Beier as quoted in Williams 1997: 125.
} 


\section{References}

\section{Newspaper articles}

Glavin, Terry 1990, Westar joins Northwest timber protest, The Vancouver Sun, February 23.

Inwood, Damian 2001, War council to battle land-claim referendum, The Province, July 20.

McInnes, Craig 1998, British Columbia changes treaty approach, The Globe and Mail, May 14.

— 1999, Nisga'a closure enrages Liberals, The Vancouver Sun, April 21.

Mickleburgh, Rod 2003, Natives vow to catch, sell BC salmon despite ruling, The Globe and Mail, August 2: A7.

Rinehart, Diane 1998a, Close vote on Nisga'a deal 'disappointment', The Vancouver Sun, November 12.

— 1998b, Nisga'a head to polls, The Vancouver Sun, November 6.

Willcocks, Paul 1999, BC government pulls plug on debate of Nisga'a treaty, The Glob and Mail, April 22.

\section{Transcripts}

Denhoff, Eric 1999, Canada, Gitanyow Main Table Meeting, Vancouver, September 17.

Weisgerber, Jack 1993, British Columbia Legislative Assembly Hansard, May 19.

Wilson, Gordon 2003, British Columbia, Official Report of Debates of The Legislative Assembly, May 25: 6482.

\section{Books, articles and reports}

Aboriginal Rights Coalition 2002, Should we vote No?, available at http://members.tripod.com/arcbc/ index.htm

Alfred, Gerald R 1995, Heeding the voices of our ancestors: Kahnawake Mohawk politics and the rise of Native Nationalism, Oxford University Press, New York.

Alfred, Taiaiake 1999, Peace, power, righteousness: an indigenous manifesto, Oxford University Press, New York.

Assembly of First Nations 2000, 'The Delgamuuk'w/ Gisday'wa National Process: Questions and answers' http://www.delgamuukw.org/news/ qa.pdf, viewed 12 November 2001.
Asch, Michael 1992, 'Political self-sufficiency' in John Bird and Diane Engelstad (eds). Nation to nation: aboriginal sovereignty and the future of Canada, Anansi, Concord Ont.

Barman, J 1996, The West beyond the West: a history of British Columbia, University of Toronto Press, Toronto.

British Columbia 1991, Ministry of Aboriginal Affairs (MAA), The Report of the British Columbia Claims Task Force (June 28), http://www.aaf.gov.bc.ca/pubs/bcctf/toc.htm, viewed 24 September 2001

— 1993, Treaty Commission Act [RSBC 1996] Chapter 461 http://www.qp.gov.bc.ca/statreg/stat/ T/96461_01.htm, viewed 12 November 2001.

— 1996, 'British Columbia's approach to treaty settlement lands and resources' (June 12) http:// www.aaf.gov.bc.ca/aaf/pubs/context.htm, viewed 12 January 2001.

— 1997, Select Standing Committee on Aboriginal Affairs, Towards Reconciliation: Nisga'a Agreement-in-Principle and British Columbia Treaty Process First Report (hereafter Towards Reconciliation) (July), Appendix II, Minority Opinions http://www.legis.gov.bc.ca/CMT/ 36thParl/CMTo1/1997/1report/index.htm, viewed 12 November 2001.

— 2000a, 'Overview of the Final McLeod Lake Adhesion to Treaty No. 8 and Settlement Agreement http://www.aaf.gov.bc.ca/newsreleases/2000/mcleodover.stm, viewed 14 January 2001.

— 200ob, 'Nisga'a Final Agreement', http://www.aaf.gov.bc.ca/treaty/nisgaa/docs/ nisga_agreement.stm, viewed 16 August 2001.

— 2001, British Columbia Statistics A Guide to the British Columbia Economy \& Labour Market (April).

— 2002a, Elections British Columbia, 'Referendum Final Results', http://www.elections.bc.ca/ referendum/finalresults.pdf, viewed 19 March 2003.

http://www.gov.bc.ca/tno/negotiation/instr_for_ negotiatiors. Htm, viewed 16 March 2003.

2003, Official report of Debates of the Legislative Assembly, May 25 
British Columbia Treaty Commission (BCTC) 1996, Update (April) http://www.bctreaty.net/updates/ aprilg6release.html, viewed 12 November 2001.

— 1999a, 'Interim report: Strengthening First Nations for treaty purposes', 7 January.

— 1999b, 'Speaking Notes for Kathleen Keating, Commissioner and Debra Hanuse, Commissioner, to the Prime Minister's Caucus Task Force on the Four Western Provinces' (Vancouver, May 17), http://www.bctreaty.net/files/task\%2oforce.pdf, viewed 12 November 2001.

— 1999c, 'Policies', http://www.bctreaty.net/files/ policies.html, viewed 12 November 2001.

- 2000), Annual Report 2000, http://www.bctreaty. net/files/annuals.html, viewed 12 November 2001.

- 2001a, Update (March), http://www.bctreaty.net/ updates/marcho1/maro1interim.html, viewed 12 November 2001.

- 2001b, Annual Report 2001, http://www.bctreaty. net/annuals/2001\%20Annual\%20Report.pdf, viewed 12 November 2001.

— 2001c, Looking back: Looking forward, http:// www.bctreaty.net/annuals/Review.pdf, viewed 12 November 2001.

- 2001d, Submission to Select Standing Committee on Aboriginal Affairs, http://www.bctreaty.net/ files/Submission $\% 20$ to $\% 20$ Select $\% 20$ Standing $\%$ 20Committee.pdf viewed 12 November 2001.

— 2002a, Update (May), http://www.bctreaty.net/ files/May\%20Update.pdf, viewed 11 March 2003.

- 2002b, Annual Report 2002, http://www.bctreaty. net/files/2002\%20Annual.pdf, viewed 11 March 2003.

— 2003a, Update (January), http://www.bctreaty. net/files/Januaryo3Update.pdf, viewed 17 March 2003.

— 2003b, Annual Report 2003, http://www. bctreaty.net/files_2/pdf_documents/ 2003\%20Annual\%20Report.pdf, viewed 30 June 2004.

— , Update (February) http://www.bctreaty.net/ files_2/pdf_documents/Febo4.pdf, viewed 30 June 2004 .

Canada 1995, The Government of Canada's Approach to Implementation of the Inherent Right and the Negotiation of Aboriginal Self-Government, Minister of Public Works and Government Services, Ottawa.
— 1997, Gathering Strength - Canada's Aboriginal Action Plan, DIAND, Ottawa.

Canada, House of Commons Special Committee on Indian Self-Government, and Penner, K 1983 , Indian self-government in Canada report of the Special Committee, Queen's Printer for Canada, Ottawa.

Canada, Task Force to Review Comprehensive Claims Policy, Coolican, $M$ and Indian and Northern Affairs Canada 1985, Living treaties, lasting agreements: report of the Task Force to Review Comprehensive Claims Policy, DIAND, Ottawa.

Canada, Royal Commission on Aboriginal Peoples 1996, The report of the Royal Commission on Aboriginal Peoples, Minister of Supply and Services, Ottawa.

Christie, Gordon 2000, 'Delgamuuk'w and modern treaties', http://www.delgamuukw.org/research/ moderntreaties.pdf, viewed 12 November 2001.

Cornell, Stephen and Joseph P Kalt nd,.... Reloading the Dice: Improving the Chances for Economic Development on American Indian Reservations (Harvard Project on American Indian Development), http://www.ksg.harvard. edu/hpaied/docs/reloading\%20the\%20dice.pdf, viewed 29 March 2003.

Council of Forest Industries 2000, Factbook, COFI, Vancouver.

Dacks, Gurston 2000, Litigation and Public Policy: Lessons from the Delgamuukw Decision, paper presented to the Joint Annual Meeting of the Canadian Political Science Association and the Société québécoise de science politique, Quebec City, Quebec.

de Costa, Ravi 2002 (unpublished), New relationships, old certainties: Australia's reconciliation and the treaty-process in British Columbia, PhD thesis, Institute for Social Research, Swinburne Institute of Technology, Melbourne.

Deloitte \& Touche 2003, British Columbia Treaty Commission: An Independent Effectiveness Review, Vancouver, BC, http://www.gov.bc.ca/tno/ down/bc_treaty_commission_review_final_dec 2_03.pdf viewed 30 June 2004 .

Derrick, Elmer 2000, Gitxsan Treaty Office, Canada Proceedings of the Standing Committee on Aboriginal Peoples, Issue no 4, Bil C-9, An Act to give effect to the Nisga'a Final Agreement 19992000, Ottawa, February 23. 
Didluck, David (2000), Executive Director Lower Mainland Treaty Advisory Committee, Interview August 14.

First Nations Education Steering Committee and British Columbia Teachers' Federation 1998, Understanding the British Columbia treaty process: an opportunity for dialogue, FNESC, Vancouver.

First Nations Summit (FNS) 1996, Treaty-making: the First Nations Summit perspective, June.

— 2001, 'The road to treaty negotiations in British Columbia', http://www.fns.bc.ca/files/tchronology.html, viewed 12 November 2001.

First Nations Summit, Union of British Columbia Indian Chiefs and Interior Alliance 2000, 'Consensus Statement' (January 29), reproduced in Interior Alliance News (July 2000).

Foster, H 1999, 'Indian administration from the Royal Proclamation of 1763 to constitutionally entrenched rights' in P Havemann (ed) Indigenous peoples' rights in Australia, Canada \& New Zealand, Oxford University Press, Auckland.

Govier, Trudy 2000, 'Trust, acknowledgment and the ethics of negotiation' in Speaking Truth to Power: A treaty forum, http://www.lcc.gc.ca/en/ress/ part/200103/traites.pdf, viewed 12 November 2001.

Hamilton, AC, Canada, and Indian and Northern Affairs Canada 1995, A new partnership, Minister of Public Works and Government Services Canada, Ottawa.

Haythornthwaite, Gabriel 2000, 'Tossing the template: British Columbia natives reject Nisga'a-style treaties', Canadian Dimension 34(5), September/ October: 33-6.

Lewis, Burke 1998, 'Into the billions and beyond', British Columbia Report (February), http://www. axionet.com/bcreport/web/980202f.html, viewed 12 November 2001].

Lovick, Dale 1998, 'Address to First Nations Summit' (Squamish Recreation Center, 29 October 1999), http://www.aaf.gov.bc.ca/news-releases/1999/ Summit-Oct.29.stm, viewed 15 January 2001.

McFarlane, Peter 1993, Brotherhood to nationhood: George Manuel and the making of the modern Indian movement, Between the Lines, Toronto.
McNeil, Kent 1998, Defining aboriginal title in the 90s: Has the Supreme Court finally got it right?, 12th Annual Roberts Lecture (Robarts Centre for Canadian Studies, York University, Toronto, March 25), http://www.delgamuukw.org/perspectives/ defining.pdf, viewed 12 November 2001.

- 1999, 'The onus of proof of aboriginal title', http://www.delgamuukw.org/research/onus.pdf, viewed 12 November 2001.

Persky, Stan 1998, Delgamuukw: the Supreme Court of Canada decision on aboriginal title, Greystone, Vancouver.

Québec 1998 edn, James Bay and Northern Québec Agreement and Complementary Agreement, Sainte-Foy, Québec.

Smith, Denise (Sliammon Chief), 2000 'Summary of proceedings/treaty panel', Island Coast Summit, http://www.islandcoastsummit.gov.bc.ca (August 9).

Snuneymuxw First Nation, British Columbia and Canada 2003, Snuneymuxw Treaty Negotiations: Draft Consultation Agreements-in-Principle Summary (April), http://www.idv8.com/ snuneymuxwtreaty/images/sfn_aipsummary.pdf, viewed 22 April 2003.

Switlo, Janice 1996, BC Treaty Process - 'trick or treaty?: giving effect to the 'spirit and intent' of treaties - abandoning treaty rights, Union of BC Indian Chiefs, Vancouver.

Tennant, Paul 1991, Aboriginal people and politics in British Columbia, University of British Columbia Press, Vancouver.

Thomas, Jeff 2003, Snuneymuxw Treaty Office, personal communication, July 21.

Tsawwassen First Nation 2000, Presentation of Treaty Negotiation Proposal (July 28, http://www. tsawwassen-fn.org/tre/comp/index.html, viewed 12 November 2001].

Wagg, Dana 2000, 'Treaty process breaking down', Raven's Eye (February 14), http://www.ammsa. com/raven/FEB200o.html\#anchor3541703, viewed 12 November 2001.

Williams, Robert 1997, Linking arms together: American Indian treaty visions of law and peace, 1600-1800, Oxford University Press, New York. 
Ravi de Costa

\section{Legislation}

The Indian Act of Canada 1876

\section{Case law}

Calder v Attorney-General of British Columbia [1973] SCR 313.

Delgamuukw v British Columbia [1997] 3 SCR 1010.

Haida Nation v BC and Weyerhaeuser [2002] BCCA 462.

Haida Nation v British Columbia (Minister of Forests) [2004] 3SCR 511.

Luuxhon et al v HMTQ Canada et al and Nisga'a Nation [2000] BCSC 1332.

Martin et al $v$ The Queen in right of the Province of British Columbia et al [1985] 3 Western Weekly Reports, 583-93.

$R v$ Kapp et al [2003], BCPC 0279

Taku River Tlingit First Nation v Ringstad et al [2002] BCCA 59.

\section{Additional website}

http:citizensassembly.bc.ca/citizensassembly.html

\section{Interviews}

Didluck, David, Executive Director Lower Mainland Treaty Advisory Committee, interview, 14 August 2000.

Krehbiel, Rick, Treaty Analyst, Lheidli T'enneh First Nation, interview, 26 August 2000.

Richardson, Miles, Chief Treaty Commissioner of British Columbia, interview, 12 October 2000.

Schulmann, Bernard, Policy Analyst Ts'kw’aylaxw First Nation, interview 23 August 2000. 